\title{
Teacher's Image of a Higher Educational Institution of the Federal Penitentiary Service of Russia during Distance Learning
}

\author{
Lyubov Fortova ${ }^{1}$, Анна Yudina ${ }^{1}$, Svetlana Komissarova ${ }^{2^{*}}$ \\ ${ }^{1}$ Vladimir State University named after Alexander Grigorievich and Nikolai Grigorievich Stoletovs, Vladimir, Russia \\ ${ }^{2}$ Vladimir Law Institute of the Federal Penitentiary Service of Russia, Vladimir, Russia \\ *Email: sveta_stepanova@mail.ru
}

\begin{abstract}
The successful activity of educational organisations operating in a new digital reality largely depends on adaptability to new realities and the speed of organising the educational process using the "digital". The digital environment completely changes the activities of a higher school teacher, who, in current conditions of interaction with students through distance educational platforms, changes and adapts the theoretical and practical material of the course being studied and the skills of interaction with students. The article raises the question of how the realities of the distance learning format influenced the formation of the teacher's image among the cadets of the departmental university. The authors attempted to study the factors that influence the authority of a teacher working in a departmental university during distance learning. Within the framework of this article, the authors conclude that students' interests, as the main subjects of educational activity, are fundamental for teachers of higher education.
\end{abstract}

Keywords: Professional ethics, Education, Professional activity, Distance learning, Teacher's image.

"The fate of education, the upbringing of the generous

personalities depend on many circumstances, including

which can be distinguished by the personality of the teacher."

(Sh.A. Amonashvili)

\section{INTRODUCTION}

This article attempts to analyse the image and authority of a teacher of a higher educational institution of the Federal Penitentiary Service of Russia during distance learning.

The purpose of the article is to argue and clarify the factors affecting the image and authority of a departmental university teacher during distance learning.

Objectives of the article: to demonstrate the relevance of the phenomenon under study; to specify the factors influencing the formation of the image of a departmental university teacher during distance learning.

Hypothesis: the image of a departmental university teacher during distance learning will be formed at a sufficiently high level if: his activities will be carried out considering the age development of cadets and relying on moral, ethical and cultural values; if his communication style is focused on mutual respect and cooperation with students in educational, scientific, professional and educational activities; if he is constantly improving in his chosen profession, attracting traditional and innovative technologies.

Methods. The analysis, synthesis, generalisation, and comparison methods were used in the work.

In the course of the work, the authors conclude that subject-subject interaction in the paradigm of a teacher cadet in a departmental university of the Federal Penitentiary Service of Russia, especially during distance learning, compliance with network etiquette in communication, improvement of professional skills, 
compliance of the teacher's dress code with the rules of internal regulations is the basis for building a further strategy for the development of a departmental university and the formation of the image of a teacher during distance learning.

In the educational process, significant periods are 2020/2021, when training sessions were transferred to an online format using digital technologies and tools. The transition to distance learning in Russia alone has covered more than 4 million students and about 240 thousand teachers [1]. The digitalisation of education is a phenomenon that has become familiar in modern society, consisting of the integration of innovative electronic technologies into the educational space of universities [2]. The coronavirus infection period motivated teachers to improve their digital competencies in the modern educational media space and provide pedagogical support for forming information and communication culture [3] of cadets of the Federal Penitentiary Service of Russia. We believe that in the digital period, thanks to the activities of teachers, new information and pedagogical potential of universities began to form. The entire pedagogical community switched to digital, mastered new educational resources and various electronic educational platforms.

\section{THE THEORETICAL PART}

A teacher of a higher educational institution in pedagogical activity is guided not only by normative legal acts but also by methodological, didactic, digital tools, and also builds communication in the "teacherstudent" paradigm based on knowledge of psychology, relying on moral, ethical and cultural values.

The profession of a teacher requires constant updating from him, which includes not only professional development and the development of teaching methods of the discipline, taking into account the general digitalisation of education in Russia, but also selfeducation and self-education, which is expressed in the desire to "keep up" with their students, taking into account the specifics of their age, psychological characteristics and motivation of the modern generation [4]. The teacher needs to choose a suitable communication style focused on mutual respect and cooperation with students in educational, scientific, professional and educational activities. During the entire training period, the teacher is a kind of standard of behaviour for cadets. Therefore, he is obliged by his actions and results to show a conscientious attitude to the matter, avoid destructive conflicts, solve contradictory situations under the norms of laws and ethics, and treat the student's religion with tolerance. The teacher needs to realise that he has no right, including moral, to show mental violence against students, to create situations of subjective assessment of the knowledge of cadets, to evaluate their results, guided by personal "likes/dislikes" in relation to specific persons, to use his official position, assisting during the examination session. In a rapidly changing world, it is necessary to maintain the quality of their professional activities and transfer knowledge at lectures and practical classes, relying on traditional and innovative technologies to develop certain competencies of students [5]. These basic attitudes are an integral component of the personality of any teacher, including those who work with cadets in higher educational institutions of the Federal Penitentiary Service of Russia. Teachers of departmental universities form and develop students' competencies in individual academic disciplines. Teaching officers broadcast through their behaviour compliance with the Code of Ethics and Official Conduct of the penal enforcement system employees. Such behaviour is expressed in a neat appearance, proper wearing of a uniform of the established pattern, compliance with internal regulations, business style of behaviour, knowledge of the legal norms governing the activities of the educational institution, respect, attentiveness and correctness to colleagues and cadets. All the requirements discussed above are an obligatory part of the professional activity of a teacher, which he should not violate because they affect the formation of his status (image) both within the service team and among students. It is the cadets who are the main object to which teachers' actions on the transfer of knowledge, skills and abilities are directed. During the training period, teachers, by their personal example, form students' attitude to study and service, participation in scientific and educational events of various levels, implementation of organisational issues. We believe that the following rule should be implemented in the modern learning process - applying the formula "pedagogical cooperation: the student is an equal participant in the pedagogical process". This formula actively manifested itself during distance learning, when the entire pedagogical community switched to online classes [6].

When organising the educational process in a digital format, teachers faced the need to abandon the usual monologue lectures and the need to organise interactive classes [7]. Given this fact, we note that many students began to evaluate the activities of teachers who switched with them to the digital format of communication during this period. Students realised that most teachers are "weak" users of educational platforms and Internet resources during this period. During this period, a new network etiquette in teacher-student communication began to form, which manifested itself in certain difficulties, which, in turn, led to a revision of the teacher's authority [8].

\section{JUSTIFICATION}

Let us describe several reasons that contributed to the formation of such a problem in the first wave of the pandemic when the entire pedagogical community 
urgently switched to a distance-learning format. First, we note technical failures during classes, which teachers did not always strive to solve. At the same time, teachers sought to transfer a certain part of the tasks to an electronic educational environment without organising online classes. In any case, this type of work implies a lack of visual communication and a violation of communication between cadets and teachers within the framework of the discipline being studied. In the electronic educational environment, it is not always possible to properly point out and explain to the cadets their mistakes during the execution of tasks. One of the reasons for this situation is the total number of students in the course, which can vary from 50 to 80 people, creating a huge burden on the teacher when evaluating works, such as in the "Moodle" program. There are cases when teachers formally approached writing reviews and giving grades for tasks performed by cadets.

It should be noted that students always see and evaluate feedback from the teacher. Such a formal approach influences the formation of the image of a teacher among students. With this style of teaching and evaluation, cadets lose motivation and interest in studying the discipline. A formal approach to completing tasks can be constructed without in-depth immersion in a problematic issue or situation. In our opinion, the most "negative" in the work of a teacher is the unwillingness of a student to study a subject, lesson, discipline. This is a signal that the teacher does not sufficiently involve the student in the process of acquiring new knowledge, including in connection with his personal formal approach, which is unacceptable in the pedagogical environment.

Secondly, during online classes, teachers did not require the inclusion of video images of students and conducted classes themselves in the "black screens" mode. This situation allowed students not to attend a particular lesson or engage in extraneous matters during lectures because the teacher did not organise feedback. We believe that "live faces" during online classes are a certain digital etiquette. Through visual presence, the teacher can determine how the cadets carry out their work (lecture notes, analysis of legal situations, work with regulatory legal sources) throughout the lesson. Moreover, by his personal example, the teacher shows how the learning space should be organised (the lighting level and the surrounding background, appearance, absence of unnecessary noise interference). Such a teacher's attitude to business communication stimulates students' desire to comply with the norms of etiquette and actively participate in the course of the lesson.

Thirdly, the digital "illiteracy" of many teachers and, at the same time, the unwillingness to improve themselves showed students that they are superior to their teachers in this area. Many teachers have realised that their students cope more successfully inside the digital education space. It should be noted that the ability to use digital tools increases the loyalty of students to the teacher [9]. The technical readiness of the teacher helps to organise online classes productively and interestingly. During distance learning, we used digital tools in realtime when conducting the disciplines "Civil Law" and "Family Law".

\section{ARGUMENTATION}

The format of Zoom conferences made it possible to use slide presentations during all types of classes, organise group discussions and a quiz with students breeding in session halls in real-time. In the "whiteboard" format, the cadets recorded their answers in the form of specific legal norms or drawings, asked the teacher and each other questions in a general chat, gave individual answers in personal messages to the teacher, took part in a survey and gave answers to the submitted test tasks [10].

As the survey showed, students of 2-3 courses in the above disciplines (training direction 40.03.01 - Law) rated the teacher's level of preparation for conducting classes as "high". The variability of such tasks in realtime stimulated students to find the right solutions when analysing practical situations, allowed them to realise their abilities when preparing presentations, to practice public speaking skills and the ability to conduct a dialogue with audiences even at a remote distance through video cameras. It should be noted that the preparation tasks were placed in advance by the teacher in an electronic educational environment so that the cadets had time to search for the necessary information, study theoretical material and get acquainted with regulatory legal sources. The work in this format was carried out systematically and showed positive results in the preparation of tasks by students, their active participation in discussions of controversial legal situations, comments on the answers of other cadets. This work assumed constant feedback from the teacher, additional preparation for conducting classes.

The authors of the article share the opinion of Ivanova A.D., who believes that an important quality in the work of a teacher is consistency, which, combined with a creative approach, allows "to get an ideal teacher" [11], who, to conduct classes in modern digital space successfully, needs not only to think over a new concept of organising the transfer of theoretical material but also to change himself. Indeed, during this period, the requirements for the quality of distance education and teachers' competencies have increased. To date, the second wave of distance learning has shown that knowledge of the basics of digital ethics and media literacy is the new norm for teachers of all levels of education. The authors of this work adhere to the provisions that one of the trends in improving the quality of education is the presence of teachers who are able to 
involve a student (cadet) in training, who have excellent knowledge of the subject and apply real (legal) cases in the learning process".

\section{CONCLUSIONS}

Teachers need to introduce practical cases into the online educational process, which it is advisable to structure and analyse together with students and practice a competitive (team) and individual approach when preparing assignments. The modern generation of cadets is more actively involved in educational activities if the material is visualised, and the teacher actively uses digital tools together with them. It should be noted that it is advisable to master the introduction of distance learning tools and technologies according to the principle: I am learning to create them, and I am learning with their help. Moreover, digital technologies open up space for new techniques that were impossible with conventional contact training. The Internet and modern information and communication technologies are of great pedagogical importance and significantly expand the foreign language dialogue space. Thus, the possession of information and communication technologies brings teachers to a new level of interaction with students, changing the mechanics of the educational process, which, of course, impacts the status of a teacher among students.

\section{REFERENCES}

[1] D.A. Shtykhno, L.V. Konstantinova \& N.N. Gagiev, Transition of universities to remote mode during the pandemic: problems and possible risks, Open education, Moscow 24(5) (2020) 72-79.

[2] I.Z. Bagaev, Education in the context of digitalisation [Obrazovanie $\mathrm{v}$ usloviyah cifrovizacii], Global Scientific Potential [Global'nyj nauchnyj potencial] 5(122) (2021) 28-30.

[3] I.K. Tsalikova, S.V. Pakhotina, Scientific Research on the Issue of Soft Skills Development (Review of the Data in International Databases of Scopus, Web of Science). The Education and science journal 21(8) (2019) 187-207 (In Russ.). DOI: https://doi.org/10.17853/1994-5639-2019-7-187$\underline{207}$

[4] L.K. Fortova, Formation of Information and Communicative Culture of Students of a Humanitarian Profile/L.K. Fortova, A.M. Yudina, A.V. Gudkova, V.A. Mashkina // Advances in social science, education and humanities research (ASSEHR): Proceedings of the International Conference «Topical Problems of Philology and Didactics: Interdisciplinary Approach in Humanities and Social Sciences» TPHD 2018. 2627 December 2018 / Editor Kh. Dz. Shambezoda. -
Dushanbe: Atlantis Press, 2019. (ASSEHR) 312 (2019) 531-534. DOI: https://doi.org/10.29

[5] D.W. Johnson \& R.T. Johnson, The impact of cooperative, competitive, and individualistic learning environments on achievement, In J. Hattie \& E. Anderman (Eds)., International handbook of student achievement, New York, Routledge, 2013, pp. 372-374.

[6] S.V. Komissarova, Theory and practice of implementing digital technologies in educational institutions of the Federal Penitentiary Service of Russia [Teoriya i praktika vnedreniya cifrovyh tekhnologij v obrazovatel'nyh organizaciyah FSIN Rossii], Global Scientific Potential [Global'nyj nauchnyj potencial] 8(125) (2021) 14-17.

[7] L.K. Fortova, Current Trends of Prevention of Delinquent Behaviour of Marginal Students / L. K. Fortova, A.M. Yudina, O.M. Ovchinnikov // Advances in social science, education and humanities research (ASSEHR): Proceedings of the International Conference "Topical Problems of Philology and Didactics: Interdisciplinary Approach in Humanities and Social Sciences" TPHD 2018, 26-27 December 2018 / Editor Kh. Dz. Shambezoda, - Dushanbe: Atlantis Press (ASSEHR) 312 (2019) 535-539. DOI: https://doi.org/10.2991/tphd-18.2019.100.

Retrieved from: https://www.atlantispress.com/proceedings/tphd-18/55916743 (accessed: 04.12.2021)

[8] N.S. Sakharova, O.V. Kabanova, Pedagogical potential of distance educational technologies nowadays, Bulletin of Orenburg State University [Vestnik Orenburgskogo gosudarstvennogo universiteta] 4(227) (2020) 41-45.

[9] T.V. Agapova, L.Yu. Aisner, The role of modern pedagogical technologies in the development of students' cognitive interests. Retrieved from: http://www.kgau.ru/new/all/konferenc/konferenc/2 018/g6.pdf (date of application: 4.12.2021).

[10] E.V. Dudusheva, O.N. Makarova, N.I. Pak, Teaching students distance technologies using distance technologies [Obuchenie studentov distancionnym tekhnologiyam s pomoshch'yu distancionnyh tekhnologij], Open and Distance Education [oshch'yu distancionnyh tekhnologij,] 4(44) (2011) 49-53. Retrieved from: https://elibrary.ru/download/elibrary_17246039_8 2221047.pdf (accessed: 04.12.2021).

[11] L.K. Fortova, Needs of Information and Communicative Culture Formation in Higher Education: Risks and Prospects / L.K. Fortova, 


\begin{abstract}
A.M. Yudina, M.S. Fabrikov, M.V. Deneko // Advances in social science, education and humanities research (ASSEHR): Proceedings of the International Conference "Topical Problems of Philology and Didactics: Interdisciplinary Approach in Humanities and Social Sciences" TPHD 2018, 26-27 December 2018 / Editor Kh. Dz. Shambezoda, Dushanbe: Atlantis Press (ASSEHR) 312 (2019) 526-530. DOI: https://doi.org/10.2991/tphd-18.2019.98 Retrieved from: $\quad$ https://www.atlantispress.com/proceedings/tphd-18/55916741 (accessed: 04.12.2021).
\end{abstract}

